\title{
Effectiveness of using comic books to communicate HIV and AIDS messages to in-school youth: Insights from a pilot intervention study in Nairobi, Kenya
}

\author{
Francis Obare ${ }^{1}$ \\ Population Council, Nairobi, Kenya \\ Harriet Birungi \\ Population Council, Nairobi, Kenya \\ Bridget Deacon \\ Well Told Story, Nairobi, Kenya \\ Rob Burnet \\ Well Told Story, Nairobi, Kenya
}

\begin{abstract}
This paper uses data from a pilot pre- and post-intervention study that was conducted in eight secondary schools in Nairobi, Kenya, between 2010 and 2011 to examine the effectiveness of using comic books to deliver HIV and AIDS messages to in-school young people. Information was collected through structured self-administered interviews with 3,624 and 2,9/4 students at baseline and endline respectively. Qualitative feedback from students was also obtained through drop-boxes. The findings show that the comic books were effective in improving students' knowledge about modes of infection, enhancing communication about the epidemic among them, positively changing their attitudes towards people living with HIV, reducing their fear and increasing their likelihood and intention of getting tested for HIV, as well as positively changing their sexual behaviours. The study underscores the need for age-appropriate communications channels to reach young people with HIV and AIDS information in settings that are affected by the epidemic.
\end{abstract}

Keywords: HIV and AIDS; communication; comic books; in-school young people; Kenya

\section{Résumé}

Cet article utilise des données provenant d'une étude pilote pré-et post-intervention qui a été menée dans huit écoles secondaires à Nairobi, au Kenya, entre 2010 et 201 I pour examiner l'efficacité de l'utilisation des bandes dessinées pour offrir les messages sur le VIH et le SIDA aux jeunes scolarisés. Des informations ont été recueillies par des interviews structurés auto-administrés avec 3.624 et 2.914 étudiants au départ et fin d'étude, respectivement. La rétroaction qualitative des étudiants a également été obtenu grâce aux boîtes de dépôt. Les résultats montrent que les bandes dessinées ont permis d'améliorer les connaissances des élèves sur les modes d'infection, l'amélioration de la communication sur l'épidémie parmi eux, modifier positivement leurs attitudes envers les personnes vivant avec le $\mathrm{VIH}$, de réduire leur peur et d'augmenter leur probabilité et leur intention de se faire tester pour VIH, ainsi que modifier positivement leurs comportements sexuels. L'étude souligne la nécessité des canaux de communication adaptés à l'âge pour atteindre les jeunes avec le $\mathrm{VIH}$ et le SIDA dans les milieux qui sont touchés par l'épidémie.

\section{Introduction}

Sub-Saharan Africa continues to bear the greatest burden of the HIV and AIDS epidemic. According to estimates by the Joint United Nations Programme on HIV/AIDS (UNAIDS), $68 \%$ of the 33.3 million people living with HIV worldwide as of 2009 were from the region (UNAIDS 2010). Besides, HIV prevalence among adults aged I5-49 years was five times higher in sub-Saharan Africa compared to other regions of the world (5\% versus $1 \%$ or less in other regions) while $69 \%$ of all new HIV infec-

I. Address for correspondence: Francis Obare, Population Council, Ralph Bunche Road, P.O. Box 17643, Nairobi 00500 Kenya. Tel: +254-20-27I3480/I/2/3; Fax: +254-20-27I3479; E-mail: fonyango@popcouncil.org 
tions worldwide were recorded in the region (UNAIDS 2010). Heterosexual contact remains the predominant mode of HIV infection in subSaharan Africa (UNAIDS 2010). In such contexts, young people aged 15-24 years are at an increased risk of being infected mainly due to involvement in unsafe sexual practices (Chatterji et al. 2005; Thurman et al. 2006). For example, HIV prevalence among young women and men aged I 5-24 years in sub-Saharan Africa was 3\% and $1 \%$ respectively as of 2009 (UNAIDS 2010). This was much higher than the prevalence among similar age groups of young people from the other regions of the world (less than $1 \%$ for young women or men from the other regions). A number of factors including socioeconomic conditions, socio-cultural practices, and weak health care systems that do not adequately meet the sexual and reproductive health needs of young people in the region contribute to their involvement in unsafe sexual behaviours, hence increased risk of HIV infection (Luke 2003; Marston and King 2006; Varga 2003; Wood and Jewkes 2003).

Behaviour change communication (BCC) is one program strategy that has been used to combat the spread of HIV and AIDS in sub-Saharan Africa. The strategy entails working with the targeted individuals and communities to develop and use communication approaches that respond to their specific needs with a view to promoting and sustaining positive behaviours. Various communication strategies have, for instance, been adopted to convey HIV and AIDS messages to different population sub-groups in the region with generally positive results in terms of the promotion of positive behaviours (Bertrand et al. 2006; Bogale et al. 20I I; Dowse et al. 20l0; Essien et al. 20I I). However, communicating sexual and reproductive health (SRH) information - including HIV and AIDS - to young people in the region has remained a complex task for a number of reasons. First, many young people have been found to espouse multiple-layered identities by expressing normative attitudes in some contexts while espousing alternative attitudes and behaviours in other contexts (Mitchell et al. 2006; Nzioka 200I). This poses a challenge with respect to determining the kind of information that should be delivered and the channels to use in specific contexts. Second, there exist socio-cultural bar- riers that define what SRH information can be communicated to them (Marston and King 2006; Mathew et al. 2006). Third, the rapid advancement in information technology may render some of the established approaches to communicating SRH information to young people - such as traditional channels and formal education - unappealing to many of them. This is because young people are always at the forefront of adapting to new technological developments (Aoki and Downes 2003; Livingstone 2002).

The foregoing suggests that young people live and follow their aspirations in complex, often conflicting and confusing reality. This underscores the need for innovative approaches for communicating SRH and HIV and AIDS information to them. Recent efforts have, for instance, involved the use of the Internet and cell phones to pass on important SRH and HIV and AIDS messages to young people (de Tolly and Alexander 2009; Halpern et al. 2008). However, the effectiveness of these approaches in the sub-Saharan Africa context might be hampered by limited access to the Internet and ownership of cell phones, especially among the poor and those in rural areas. Although these channels are easily accessible in many urban areas in the region, their use in the school setting might be limited by regulations aimed at ensuring that students concentrate more on academic work than on surfing the Internet or communicating through the phone. This paper therefore examines the effectiveness of using a different approach in the school setting - comic books - to deliver HIV and AIDS messages to young people using data from a pilot intervention study that was conducted in Nairobi, Kenya. It specifically considers changes, if any, in knowledge, attitudes and practices of students regarding HIV and AIDS as a result of using comic books to communicate relevant information.

\section{Theoretical and conceptual considerations}

The pilot study involved communications interventions based on the BCC approach, which hinges on Social Cognitive and Self-Efficacy theories (Bandura 1977, 1986), the Health Belief Model (Becker 1974), the Theory of Reasoned 
Action and its extension, the Theory of Planned Behaviour (Azjen 1985; Fishbein \& Ajzen 1975). According to Social Cognitive theory, an individual's behaviour is a result of the interaction between cognition, environment, and physiology. In the context of HIV and AIDS prevention, self-efficacy (one's perceived ability to adopt a particular behaviour) and role models are important dimensions for behaviour change (Airhihenbuwa and Obregon 2000). The Health Belief Model, on the other hand, stipulates that an individual's adoption of a particular behaviour is determined by the perceived seriousness of the condition as well as by perceived benefits of and barriers to adopting the behaviour. The Theory of Reasoned Action, on the other hand, states that an individual's behaviour is predicted by intention, which in turn is determined by attitude toward and social norms regarding the behaviour. The Theory of Planned Behaviour extends this postulation to include perceived control over the behaviour. These theories have been used to examine social and health outcomes and to inform the design of health interventions including HIV and AIDS prevention programmes in different regions of the world (see for example, Albarracín et al. 2006; MuñozSilva et al. 2007; Reinecke et al. 1996; Sullivan et al. 2006; Vanlandingham et al. 1995).

The BCC approach that is based on these theories is specifically premised on the notion that before individuals can reduce their levels of risk or change their behaviours, they need to first understand the basic facts about HIV and AIDS, adopt positive attitudes, acquire a set of skills, and have access to appropriate services (Family Health International [FHI] 2002, 2005). In addition, they need to perceive that their environment is conducive to behaviour change, the maintenance of positive behaviours, and the seeking of appropriate services (FHI 2002, 2005). Besides these theoretical approaches to social change communications, the interventions built on entertainment-education as a communication strategy for achieving such change (Rogers et al. 1999; Singhal and Rogers 1999; Singhal et al. 2004). This strategy involves the use of role models to accelerate learning, self-belief and empowerment in audiences by demonstrating best and worst practices and potential outcomes in characters that are familiar to them. The interventions were further informed by the
Two-Step Flow theory of communication (Lazarsfeld et al. 1948) in which a number of key receivers or "early adopters" help transmit messages to others through informed discussion that leads to multiple actions.

The overall objective of the study was to test the acceptability and effectiveness of using comic books and role models to: (I) increase awareness about HIV and AIDS among students, (2) enhance communication about HIV and AIDS among students as well as between students and their teachers, parents or guardians, (3) positively change students' attitudes towards people living with HIV, (4) generate a demand for HIV services among students, and (5) positively change students' sexual behaviour. The use of comic books and role models was aimed at inspiring students to believe in their ability to adopt positive behaviours and was therefore informed by the Social Cognitive and Self-Efficacy theories. The HIV and AIDS messages that were conveyed through the comic books and by the role models were aimed at enhancing students' perceptions about the disease and the benefits of adopting positive behaviour as stipulated by the Health Belief Model. Changes in students' perceptions and attitudes were in turn expected to lead to changes in their behaviours according to the Theory of Reasoned Action and the Theory of Planned Behaviour. The mode of conveying the messages was informed by entertainment-education as a communication strategy. In addition, given that not all students were exposed to the interventions, the study assumed that those who received the messages would transmit them to their peers as the TwoStep Flow theory stipulates.

It could be argued that since there have been numerous campaigns aimed at mitigating the spread of HIV in many parts of sub-Saharan Africa that are affected by the epidemic, awareness about it should be high. Indeed evidence from the Demographic and Health Surveys show levels of awareness about HIV and AIDS in the region ranging from $80 \%$ to $99 \%$. However, this level of awareness refers to whether an individual has heard about HIV and AIDS and might not reflect detailed knowledge about such aspects as mode of infection, availability of treatment and care, as well as how to cope with infection. In Kenya, for example, although $99 \%$ of women aged 15-49 years had heard about 
HIV and AIDS, only $49 \%$ had comprehensive knowledge of it, that is, knew means of protection against infection and rejected misconceptions about the virus (Kenya National Bureau of Statistics [KNBS] and ICF Macro 20I0). Moreover, knowledge of HIV and AIDS among young people may be affected by a cohort effect in cases where other pressing health priorities take precedence. Thus, those who transition to adolescence and early adulthood during the period when there is little emphasis on HIV and AIDS might not have detailed knowledge about it.

With respect to enhancing communication about HIV and AIDS, it was expected that increased interpersonal communication would in turn positively change the attitudes and practices of students regarding the epidemic. Personal communication networks have, for instance, been found to influence attitudes and practices regarding family planning and HIV and AIDS in parts of sub-Saharan Africa (Bühler and Kohler 2003; Helleringer and Kohler 2005; Kohler et al. 2001; Watkins 2004). Related to this is the fact that stigma and discrimination against people living with HIV are still prevalent in many parts of the region (Bond et al. 2002; Skinner and Mfecane 2004; Ward and Mendelsohn 2009). These often arise from fear of HIV transmission or infection from casual contact, and from associating infection with behaviour that is considered immoral (Nyblade et al. 2003). In school settings, stigma and discrimination against students living with HIV not only have serious psychosocial consequences on them but also determine whether they remain in school and affect their academic performance as well (Birungi et al. 201 I; Obare et al. 2009; Ward and Mendelsohn 2009). Moreover, those who are on anti-retroviral treatment (ART) and are in boarding institutions face additional challenges with respect to adherence to treatment because of fear of stigma and discrimination from fellow students (Obare et al. 2009). The study therefore sought to change students' attitudes towards people living with HIV by providing information on the consequences of stigma and discrimination to those who are exposed to them using familiar stories.

Besides abstinence, partner fidelity and condom use, testing and counselling is one strategy that has been promoted to stem further spread of HIV in sub-Saharan Africa. HIV testing offers a vital opportunity to inform or remind young people of how they can protect themselves while early detection of HIV infection can enable them to start treatment sooner, thereby fostering positive health outcomes and longevity (Centers for Disease Control and Prevention 2009). However, evidence from the Demographic and Health Surveys (DHS) shows that although young people initiate sexual activity early, the level of condom use is low. In Kenya, for instance, young people commence sexual activity as early as age eight; among $39 \%$ of adolescents aged 15-19 years who had ever had sex, only $28 \%$ used a condom at first sex and $22 \%$ used a condom at last sex (KNBS and ICF Macro 2010). At the same time, only a small proportion of adolescents aged 15-19 years have been tested for HIV and obtained test results $(35 \%$ of female and $23 \%$ of male adolescents) although a sizeable number may have been exposed to the risk of infection (KNBS and ICF Macro 20I0). The study thus sought to promote early diagnosis and testing for HIV among students by providing information that would enable them make decisions and increase their personal conviction regarding the benefits of knowing and managing one's sero-status. It was anticipated that the combined effects of the interventions on awareness, communications, attitudes and uptake of HIV services would result in positive changes in the sexual behaviour of students.

\section{Data and methods}

\section{Study design}

The paper uses data from a pilot pre- and postintervention study without a comparison group that was implemented between 2010 and $201 \mathrm{I}$ in eight secondary schools in Nairobi, Kenya. The schools were identified by the Ministry of Education based on level (national or provincial), composition (single sex or mixed), institutional arrangement (day or boarding), socio-economic setting (high-, medium- or low-income), and geographical location (western, eastern, southern, northern or central parts of the city). The project directly targeted in-school adolescent boys and girls aged 12-19 years, hence the focus on secondary schools given that most young people within this age range are at this 
level of schooling. It also directly targeted the teachers as well as school nurses and matrons in the selected schools. It further aimed at indirectly reaching the parents/guardians of students enrolled in the participating schools. Formative research involving group discussions and written essays with students, teachers and parents/guardians from six of the eight schools was first conducted in late 2010 to obtain information to guide the design of the interventions. The groups were selected based on the nature and composition of each school. For instance, discussions with groups of parents were only possible in day schools where they could be readily mobilized. Each group comprised about six participants and had a facilitator and a notetaker. The discussions were, however, not taperecorded.

A series of consultative meetings were held with provincial and district-level education managers in Nairobi, principals of the participating schools, and representatives from non-governmental organizations and bilateral donors with interests in the education sector before the implementation of the study. The purpose of the meetings was to discuss the challenges that HIV poses to the education sector in Kenya, brief the participants about the project, and obtain their views. During the meeting with the principals of participating schools, each one of them was requested to identify two teachers from their schools to work with the project. A separate meeting was then held with the identified teachers, who were mostly guidance and counseling teachers, to brief them about the project and to prepare a work plan. The project also hired a full-time study coordinator to work with the teachers on organizing project activities within the schools.

\section{Interventions activities}

The interventions involved communications activities that were carried out in two phases over a period of five months during the school year. The first phase involved developing and distributing communications materials. These included a series of three colourful comic books for students together with accompanying guides for parents/guardians and teachers as well as colourful posters for classrooms and staff rooms. Each of the three series of the comic books and guides focused on a specific theme on HIV and AIDS. The first series addressed issues of communicating about HIV and AIDS, the second focused on the need for testing and counselling for HIV, while the third dealt with stigma and discrimination and their consequences on those who are exposed to them. The parents' and teachers' guides were designed to assist them in talking about HIV and AIDS with their children/students. The posters had key messages on HIV and AIDS and appropriate slogans derived from the comic book stories. The materials were first pre-tested with a group of students, teachers and parents from schools not participating in the project. The pretest involved showing them the pre-print copies of the materials and then soliciting their views on the colour, content and language. The feedback was used to improve on the materials before printing for distribution to schools participating in the project. The comic books and teachers' guides were in English while the guide for parents was in both English and Kiswahili, the national language. All the communications materials were developed, pre-tested, and distributed to the participating schools between February and April 20I I by Well Told Story, a social communications design, production and consulting firm based in Kenya.

The comic books were distributed to all students in the participating schools who were present on the day the materials were delivered to the schools. The books were entitled Kuwa Shujaa (Kiswahili term for 'be a hero') as a way of inspiring students to be champions of positive behaviour and were based on role model characters and familiar scenarios and locations. The books were designed to illustrate best and worst practices, combine drama with factual information, and raise important issues and questions aimed at fostering debate about HIV and AIDS among students as well as between students and their teachers, parents or guardians. They also included interactive activities for students to undertake such as raising questions or concerns and expressing their thoughts through word and art. Students were, for instance, challenged to write down their thoughts about HIV and AIDS, turn these into eye-catching posters that would convey the message to the people around them, and share their posters with their colleagues. In each school, the launch of the first series of the comic 
books and guides was accompanied by educative performance by a local musician (whose image was also used in the comic books) and a local actor. The educative performances were used to convey the key messages on HIV and AIDS to students under the slogan: know your status, plan your future.

Drop-boxes were also distributed to the participating schools for students to drop in questions or concerns they had on SRH, HIV and AIDS. During the second phase of the interventions, health experts from the Ministry of Pubic Health and Sanitation visited the schools to respond to the questions and concerns that the students had raised. The health talks were also accompanied by educative performance by the local musician. A total of 14,700 comic books, 6,900 teachers' guides, and 4,000 parents' guides were distributed to the schools while 13 educative performances were conducted during the intervention period. The guides for parents/guardians were distributed during school open days, annual general meetings, and parents-teachers association meetings.

\section{Data collection}

Data were collected through quantitative and qualitative approaches. Quantitative data were collected before (January 20 II) and after (September 201I) the interventions from among 3,624 and 2,9/4 students at baseline and endline respectively. It involved the use of structured self-administered questionnaire to assess students' attitudes towards information on HIV and AIDS, testing, counselling, stigma and discrimination. Information was collected on sources and contents of HIV and AIDS information at school, experiences with and intentions regarding HIV testing and counselling, attitudes towards HIV-positive students, sexual behaviour, and at endline, exposure to and experiences with the interventions. The questionnaire was in English and was pre-tested among a group of five students who were identified with the help of Population Council staff members based in Nairobi.

All students who were present on the day scheduled for interviews and for whom parental/guardian and individual consent was obtained were eligible to complete the questionnaire. The study coordinator was responsible for distributing the consent forms for parents/guardians to schools before the scheduled dates of interviews while the consent forms for students were distributed together with the questionnaire on the day of the interview. The interviews were anonymous: students were instructed not to write any identifying information such as name or registration number on the questionnaires. The questionnaires were distributed by research assistants who explained the purpose of the study, obtained individual written consent from participants, and remained in the room during the period to answer any procedural or substantive questions. The students completed the questionnaires in their respective classrooms with each student taking an average of 30 minutes. The exercise was scheduled in collaboration with the participating schools at convenient times in order not to interfere with the normal school lessons.

Qualitative data, on the other hand, came from comments that were placed in the dropboxes by students which were collected and collated at the end of the interventions. The project obtained ethical and research clearance from the Kenya Medical Research Institute (KEMRI), the Population Council Institutional Review Board, and the National Council for Science and Technology (NCST).

Methods of analysis

Analysis of quantitative data entails estimation of random-effects logit models that take into account the unmeasured characteristics of students from the same school. The model is specified as:

$$
\log i t\left(\pi_{i j}\right)=\beta X_{i j}+\mu_{j}
$$

where $\pi_{i j}$ is the probability of a given outcome for student $i$ in school $j ; X_{i j}$ is the vector of measured covariates; $\beta$ is the associated vector of fixed parameters, and ${ }_{j}$ is the error term due to unmeasured characteristics that also affect the outcome for students in school $j$. 
The outcomes considered include knowledge of at least one mode of HIV transmission, talking to anyone about HIV and AIDS, expressing positive attitudes towards people living with HIV, and whether the student would accept HIV testing and counselling if offered, was tested for HIV in the last five months preceding the interview, and had had sexual intercourse in the last one month before the survey. The independent variable of interest is whether the student obtained and read the comic books as opposed to getting the materials and not reading them or not getting them at all. The models control for the point of study (baseline or endline), age (in single years), sex (male or female), institutional arrangement (boys' boarding, girls' boarding or mixed day), and whether the respondent usually lived with biological parents. The qualitative feedback from students is, on the other hand, analyzed for content and specific quotes are provided to support findings from the quantitative data.

\section{Results}

Characteristics of students

Table I presents the percentage distribution of students who participated in the baseline and endline interviews by background characteristics. There were significant variations between baseline and endline in the distribution of students by age, sex, and institutional arrangement. Although more than three-quarters of the students who participated in either baseline or endline interviews were aged between 15-19 years, the proportion was significantly higher at baseline than at endline. Moreover, more than half of the students who participated in the baseline interviews were male, while at endline, female respondents comprised more than half of the participants. The distribution of students by institutional arrangement is similar to that of sex. There was, however, no significant difference between baseline and endline in the distribution of students according to who they usually lived with.

Table I Percentage distribution of study participants by background characteristics

\begin{tabular}{|c|c|c|c|}
\hline Characteristics & $\begin{array}{l}\text { Baseline } \\
(\%)\end{array}$ & $\begin{array}{l}\text { Endline } \\
(\%)\end{array}$ & $\begin{array}{l}\text { All students } \\
(\%)\end{array}$ \\
\hline Age group (years) & $\mathrm{p}<0.01$ & & \\
\hline$<15$ years & 6.4 & 15.8 & 10.6 \\
\hline $15-19$ & 84.9 & 76.8 & 81.3 \\
\hline 20 years and above & 2.4 & 2.5 & 2.5 \\
\hline Missing & 6.3 & 4.9 & 5.7 \\
\hline Sex & $\mathrm{p}<0.0 \mathrm{l}$ & & \\
\hline Male & 52.4 & 46.4 & 49.8 \\
\hline Female & 47.1 & 53.6 & 50.0 \\
\hline Missing & 0.5 & 0.0 & 0.3 \\
\hline Institutional arrangement & $\mathrm{p}<0.01$ & & \\
\hline Boys' boarding & 40.5 & 38.4 & 39.5 \\
\hline Girls' boarding & 38.4 & 47.9 & 42.7 \\
\hline Mixed day & 21.1 & 13.7 & 17.8 \\
\hline Person(s) respondent usually lived with & $p=0.93$ & & \\
\hline Biological parent(s) & 85.9 & 85.9 & 85.9 \\
\hline Relative(s) & 8.4 & 8.6 & 8.5 \\
\hline Alone & 2.2 & 2.3 & 2.2 \\
\hline Friend(s)/other & 2.2 & 2.3 & 2.2 \\
\hline Missing & 1.5 & 0.8 & 1.2 \\
\hline Respondent obtained and read comic books & $\mathrm{p}<0.01$ & & \\
\hline Obtained and read & 0.0 & 79.8 & 35.6 \\
\hline Obtained but did not read & 0.0 & 1.4 & 0.6 \\
\hline Did not obtain & 100.0 & 8.4 & 59.2 \\
\hline Missing & 0.0 & 10.4 & 4.7 \\
\hline Number of students & 3,624 & 2,914 & 6,538 \\
\hline
\end{tabular}


Knowledge of modes of HIV transmission

Results from the random-effects logit analysis predicting knowledge of modes of HIV transmission show that students who obtained and read the comic books were three times significantly more likely to know at least one mode compared to their counterparts who either obtained but did not read or never obtained the materials (Table 2). Improvement in knowledge of modes of HIV transmission among students who obtained and read the comic books is further supported by the following excerpts:

'Kuwa Shujaa' helped me learn that HIV cannot be spread by shaking hands and that you cannot tell someone's status by looking at their physical appearance ... Thank you for giving this important information (Mixed day school).

You have been of great help to me and my friends in school. You answered some of our questions like if a person can be infected with HIV by kissing. Thanks and keep spreading the information about HIV/AIDS (Girls' boarding school).

Table 2 Odds ratios from the random-effects logit models predicting HIV and AIDS-related knowledge, attitude and practice outcomes among students

\begin{tabular}{|c|c|c|c|c|c|c|}
\hline Covariates & $\begin{array}{l}\text { Knows at least } \\
\text { one mode of HIV } \\
\text { transmission }\end{array}$ & $\begin{array}{l}\text { Talked to } \\
\text { anyone } \\
\text { about HIV } \\
\text { and AIDS }\end{array}$ & $\begin{array}{l}\text { Expressed } \\
\text { positive } \\
\text { attitude } \\
\text { towards PLWH }\end{array}$ & $\begin{array}{l}\text { Would accept } \\
\text { HIV testing/ } \\
\text { counselling }\end{array}$ & $\begin{array}{l}\text { Tested for } \\
\text { HIV last five } \\
\text { months }\end{array}$ & $\begin{array}{l}\text { Had sex } \\
\text { last one } \\
\text { month }\end{array}$ \\
\hline $\begin{array}{l}\text { Obtained and read comic } \\
\text { books }(\text { Yes }=1)\end{array}$ & $\begin{array}{l}3.0 * * \\
(2.1-4.4)\end{array}$ & $\begin{array}{l}1.5^{* *} \\
(1.2-1.9)\end{array}$ & $\begin{array}{l}3.4 * * \\
(2.4-4.8)\end{array}$ & $\begin{array}{l}2.6 * * \\
(2.0-3.2)\end{array}$ & $\begin{array}{l}1.6^{*} \\
(1.1-2.4)\end{array}$ & $\begin{array}{l}0.6 * * \\
(0.5-0.9)\end{array}$ \\
\hline $\begin{array}{l}\text { Point of study (Endline }= \\
\text { I) }\end{array}$ & $\begin{array}{l}0.4 * * \\
(0.3-0.5)\end{array}$ & $\begin{array}{l}0.5^{* *} \\
(0.4-0.6)\end{array}$ & $\begin{array}{l}0.4 * * \\
(0.3-0.6)\end{array}$ & $\begin{array}{l}0.5 * * \\
(0.4-0.6)\end{array}$ & $\begin{array}{l}0.4 * * \\
(0.3-0.6)\end{array}$ & $\begin{array}{l}1.0 \\
(0.7-1.4)\end{array}$ \\
\hline \multicolumn{7}{|l|}{ Age (ref: < I5 years) } \\
\hline $15-19$ years & $\begin{array}{l}0.9 \\
(0.6-1.5)\end{array}$ & $\begin{array}{l}0.8 * * \\
(0.6-0.9)\end{array}$ & $\begin{array}{l}0.3^{* *} \\
(0.2-0.6)\end{array}$ & $\begin{array}{l}0.6 * * \\
(0.5-0.8)\end{array}$ & $\begin{array}{l}1.4^{*} \\
(1.0-2.1)\end{array}$ & $\begin{array}{l}2.9 * * \\
(1.8-4.5)\end{array}$ \\
\hline 20 years and above & $\begin{array}{l}0.4^{* *} \\
(0.2-0.7)\end{array}$ & $\begin{array}{l}1.0 \\
0.7-1.6)\end{array}$ & $\begin{array}{l}0.2^{* *} \\
(0.1-0.4)\end{array}$ & $\begin{array}{l}0.4^{* *} \\
(0.2-0.6)\end{array}$ & $\begin{array}{l}1.4 \\
(0.8-2.4)\end{array}$ & $\begin{array}{l}11.3 * * \\
(6.3- \\
20.1)\end{array}$ \\
\hline Sex $($ Female $=I)$ & $\begin{array}{l}0.8 \\
(0.5-1.3)\end{array}$ & $\begin{array}{l}1.7 * * \\
(1.3-2.4)\end{array}$ & $\begin{array}{l}2.1 * * \\
(1.2-3.5)\end{array}$ & $\begin{array}{l}1.4 \\
(0.9-1.9)\end{array}$ & $\begin{array}{l}1.0 \\
(0.7-1.4)\end{array}$ & $\begin{array}{l}0.5^{* *} \\
(0.3-0.7)\end{array}$ \\
\hline \multicolumn{7}{|l|}{$\begin{array}{l}\text { Institutional arrangement } \\
\text { (ref = Boys' boarding) }\end{array}$} \\
\hline Girls' boarding & $\begin{array}{l}1.9 * \\
(1.0-3.7)\end{array}$ & $\begin{array}{l}1.0 \\
(0.4-2.7)\end{array}$ & $\begin{array}{l}0.9 \\
(0.4-2.2)\end{array}$ & $\begin{array}{l}1.4 \\
(0.8-2.6)\end{array}$ & $\begin{array}{l}1.4 \\
(0.3-6.3)\end{array}$ & $\begin{array}{l}1.0 \\
(0.6-1.8)\end{array}$ \\
\hline Mixed day & $\begin{array}{l}0.8 \\
(0.5-1.4)\end{array}$ & $\begin{array}{l}1.4 \\
(0.6-3.5)\end{array}$ & $\begin{array}{l}1.1 \\
(0.6-2.3)\end{array}$ & $\begin{array}{l}1.5 \\
(0.9-2.6)\end{array}$ & $\begin{array}{l}2.8 \\
(0.6-12.3)\end{array}$ & $\begin{array}{l}0.9 \\
(0.6-1.5)\end{array}$ \\
\hline $\begin{array}{l}\text { Respondent usually lives } \\
\text { with biological parents } \\
(\text { Yes }=I)\end{array}$ & $\begin{array}{l}1.5^{*} \\
(1.1-2.0)\end{array}$ & $\begin{array}{l}0.9 \\
(0.8-1.2)\end{array}$ & $\begin{array}{l}1.3 \\
(0.9-1.8)\end{array}$ & $\begin{array}{l}\text { I.3** } \\
(1.1-1.6)\end{array}$ & $\begin{array}{l}0.7^{*} \\
(0.6-0.9)\end{array}$ & $\begin{array}{l}0.6 * * \\
(0.5-0.7)\end{array}$ \\
\hline Number of cases & 6,033 & 5,682 & 5,854 & 5,737 & 6,033 & 6,033 \\
\hline
\end{tabular}

Notes:PLWH: People living with HIV; Estimates are based on Equation (I) in the text; $95 \%$ confidence intervals are in parentheses; ref: reference category; ${ }^{*} \mathrm{p}<0.05 ;{ }^{*} \mathrm{p}<0.01$.

The results further show that the likelihood of reporting knowledge of at least one mode of HIV transmission was significantly higher among students who usually lived with biological parents than among those who lived with other persons and among students in girls' boarding than those in boys' boarding or mixed day schools (Table 2). Nonetheless, the likelihood of such knowledge was significantly lower at endline than at baseline and among students aged 20 years and above than among their younger counterparts.
Communicating about HIV and AIDS

The comic books and the use of role models were intended to provide students with basic facts about HIV and AIDS through channels that are entertaining and appealing in order to stimulate informed discussions. The results from the random-effects logit analysis show that students who obtained and read the comic books were I.5 times significantly more likely to have talked to someone about HIV and AIDS compared to those who obtained but did not read or those that never obtained the materials (Table 2). This was corroborated by comments from students 
who reported openly talking about HIV and AIDS and also recognized the importance of the comic books for improving parent-child communication as exemplified by the following quotes:

This book is cool, inspiring and very educative. The stories are real and I am glad I can learn a lot now. I am even open now talking about HIVIAIDS ... Please lengthen the stories. Thank you very much (Girls' boarding school).

\section{The 'Mwelekeo wa Wazazi' [parents' guide]} is excellent in educating parents on how to relate with their sons and daughters (Girls' boarding school).

The results in Table 2 also show that female students were significantly more likely to report talking to someone about HIV and AIDS compared to male students. However, the likelihood of talking to anyone about HIV and AIDS was significantly lower at endline than at baseline and among those aged 15-19 years compared to those aged below 15 years.

\section{Attitudes towards people living with HIV}

Students who obtained and read the comic books were 3.4 times significantly more likely to support the inclusion of HIV-positive children in schools compared to those who did not obtain or read the materials (Table 2). Positive changes in students' attitudes towards people living with HIV were also evident from the qualitative feedback obtained through the drop-boxes as shown by the following excerpts:

I am very happy because 'Kuwa Shujaa' made me know how to live with people living with HIVIAIDS. We should not discriminate against them because it is not their wish to be HIV positive (Mixed day school).

Personally I am a victim not because I am infected but because I had to go to primary school with HIV-infected pupils whom I was afraid of. The comic has challenged me to accept them and evaluate myself (Girls' boarding school).

Similar to communication about HIV and AIDS, female students were significantly more likely to express positive attitudes towards children liv- ing with HIV than their male counterparts (Table 2 ). The likelihood of expressing positive attitudes towards HIV-positive children was, however, significantly lower among older than among younger students and at endline than at baseline.

\section{HIV testing and counselling}

With respect to HIV testing and counselling, students who obtained and read the comic books were $\mathbf{2 . 6}$ times significantly more likely to report that they would accept the services if offered compared to their counterparts who did not obtain or read the materials (Table 2). In addition, the likelihood of being tested for HIV in the five months preceding the interview was I.6 times significantly higher among those who obtained and read the comic books than among those who did not. Excerpts from qualitative feedback from students further indicate that there was reduced fear of getting tested for HIV and increased intention to get tested as a result of the information obtained from the comic books as the following quotes show:

Thanks 'Kuwa Shujaa'. I have now made a decision to get tested (Boys' boarding school).

'Kuwa Shujaa' has opened my eyes and helped me know that every person going or seen in or around a VCT [voluntary counselling and testing centre] is not HIV positive ...When I read 'Kuwa Shujaa', I went for test and I am happy that I am now aware of my status (Mixed day school).

The likelihood of being tested for HIV in the five months before the survey was also significantly higher among students aged 15-19 years compared to those aged below 15 years (Table 2). It was, however, significantly lower at endline than at baseline and among students who usually lived with biological parents than among those who lived with other persons.

\section{Sexual behaviour}

The ultimate aim of the interventions was to positively change the sexual behaviour of students with a view to reducing their risk of HIV infection. Results from the random-effects logit analysis show that students who obtained and read the comic books were significantly less likely to have had sex in the one month before 
the interview compared to those who did not obtain or read the materials. At both baseline and endline, the month preceding the interview date referred to the period when schools were on recess, hence high chances of engaging in intercourse for those who were sexually active. Changes in the sexual behaviour of students were further evident from the qualitative feedback obtained through the drop-boxes as the following quotes show:

\section{'Kuwa Shujaa' has helped me learn that I can avoid sex by trying not to be idle (Mixed day school).}

To me it has helped me avoid peer pressure because when I read about Jipendo [character in the comic books], it is really discouraging peer pressure. Thank you very much and I would request for more comic books (Girls' boarding school).

The results further show that the likelihood of having had sex in the one month before the interview was significantly lower among female than among male students and among those who usually lived with biological parents than among those who lived with other persons (Table 2). Nonetheless, older students were significantly more likely to have had sex in the one month before the interview compared to their younger counterparts.

\section{Discussion and implications}

Many countries in sub-Saharan Africa that are affected by the HIV and AIDS epidemic have either instituted or enhanced SRH education in schools with a view to reaching young people with important SRH information aimed at promoting positive sexual behaviours and reducing their risk of being infected with HIV and other sexually transmitted infections (Gallanta and Maticka-Tyndale 2004; Kaaya et al. 2002). School-based SRH education may, however, be limited by the socio-cultural and policy environment, the technical capacity of teachers to conduct such education, as well as by technological advancements that may render traditional teaching approaches unappealing to many young people (Aoki and Downes 2003; Livingstone 2002; Marston and King 2006; Mathew et al. 2006; Mathews et al. 2006; Oshi et al. 2005).
This paper therefore provides insights from a pilot intervention study that was conducted in Nairobi, Kenya, that used comic books to communicate HIV and AIDS information to in-school young people. The comic books were meant to inspire students through their colourfulness and the title, a combination of drama and factual information, as well as through the use of role model characters and stories that were familiar to them. The findings show that the approach was effective in improving students' knowledge about modes of infection, enhancing communication about the epidemic among them, positively changing their attitudes towards people living with HIV, reducing their fear and increasing their likelihood and intention of getting tested for HIV, as well as positively changing their sexual behaviours.

The above findings are consistent with the theoretical expectations outlined earlier. For instance, the feedback from students showed that the comic books inspired them to espouse positive behaviour. The HIV and AIDS messages, on the other hand, positively changed their perceptions about the disease as well as their attitudes towards HIV-positive students. In addition, the interventions not only increased their intentions of getting tested for HIV but also their chances of getting tested. Furthermore, positive changes in behaviour were evident from reduced chances of having had sexual intercourse in the one month prior to the interview date among students exposed to the interventions compared to those that were not. The findings are also consistent with existing literature which shows that interventions that are based on theories such as the Theory of Reasoned Action, the Theory of Planned Behavior, Social Cognitive and Self-Efficacy theories, and information-motivation and behavioral-skills models are effective in changing attitudes and behaviours compared to interventions aimed at instilling fear (Albarracín et al. 2006). The findings are further consistent with available evidence showing that school-based sexuality and HIV and AIDS education are effective in improving sexual and reproductive health outcomes for young people (Kaaya et al. 2002; Kirby et al. 2006).

It is, however, worth noting that the findings may be influenced by the study's limitations. First, the busy school schedules meant that the 
activities had to be conducted during weekends or in the evening during weekdays after classes. This may have left out some students, especially in day schools. It could also partly explain the significant differences in the characteristics of students who participated in baseline and endline interviews as well as the significantly lower likelihood of the outcomes at endline compared to baseline. Moreover, although it would have been desirable to restrict the analysis to only those students who participated in both baseline and endline interviews, it was not possible to collect identifying information to determine which students participated in both interviews due to ethical reasons. Another limitation arises from the use of self-administered questionnaires which did not allow for clarification of unclear terms and probing for additional information or detail. This may have led to cases of missing responses for questions the students did not clearly understand or felt uncomfortable with. The use of self-administered questionnaires was, however, meant to ensure confidentiality and privacy of students with the hope that this would make them respond honestly to the questions. The study was also piloted in urban secondary schools only due to funding limitations. Although the Ministry of Education selected the pilot schools based on criteria that characterize most secondary schools in the country (level, sex composition, institutional arrangement, socio-economic setting, and geographical location), the experiences may not be similar to those of rural schools.

Despite the limitations, the study findings underscore the need for age-appropriate communication channels to reach young people with HIV and AIDS information in settings that are affected by the epidemic. The study further highlights the need for involvement of relevant education and health sector stakeholders (health and education managers, teachers, parents/guardians, and students) in the conceptualization and design of appropriate channels and messages to ensure that they are acceptable and feasible within the school setting. For instance, through the involvement of various stakeholders, the project designed messages and channels of communicating those messages that took into account the Ministry of Public Health and Sanitation's policy regarding HIV prevention, the Ministry of Education's policy that does not permit the promotion of condoms in schools in Kenya, and the views of parents/guardians, teachers, and the students themselves. This could partly explain why the approach was effective in changing students' HIV and AIDS-related knowledge, attitudes and practices.

\section{Acknowledgements}

The pilot study was funded by the United States Agency for International Development (USAID)-Kenya Mission through cooperative agreement 623-A-00-09-0000I-00 with the Population Council. It was implemented by APHIA II Operations Research Project in collaboration with the Ministry of Education, Well Told Story, and the Ministry of Public Health and Sanitation. The Institutional Review Board of the Population Council, the Ethics Review Committee of the Kenya Medical Research Institute (KEMRI) and the National Council for Science and Technology (NCST) granted ethical and research clearance for the study. An earlier version of the paper benefited from valuable comments from anonymous reviewers. The opinions expressed in this paper are, however, those of the authors and do not necessarily reflect the views of the funding or implementing agencies.

\section{References}

Airhihenbuwa, C.O. and Obregon, R. 2000. "A critical assessment of theories/models used in health communication for HIV/AIDS." Journal of Health Communication 5, (Suppl):5-I5.

Albarracín, D., Durantini, M.R. and Earl, A. 2006. "Empirical and theoretical conclusions of an analysis of outcomes of HIV-prevention interventions." Current Directions in Psychological Science, 15(2): 73-78

Aoki, K. and Downes, E.J. 2003. "An analysis of young people's use of and attitudes toward cell phones." Telematics and Informatics 20, (4):349364.

Ajzen, I. 1985. "From intentions to actions: A theory of planned behavior." In: J. Kuhl and J. Beckmann (eds). Action-control: From cognition to behavior. Heidelberg: Springer, pp. I I-39.

Bandura, A. 1986. Social Foundations of Thought and Action: Social Cognitive Theory. Englewood Cliffs: Prentice-Hall.

Bandura, A. 1977. "Self-efficacy: Toward a unifying theory of behavioural change." Psychological Review 84, (2): 191-215. 
Becker, M.H. 1974. The Health Belief Model and Personal Health Behavior. $2^{\text {nd }}$ ed. San Francisco: Society for Public Health Education.

Bertrand, J.T., O'Reilly, K., Denison, J., Anhang, R. and Sweat, M. 2006. "Systematic review of the effectiveness of mass communication programs to change HIV/AIDS-related behaviors in developing countries." Health Education Research 2I, (4):567-597.

Birungi, H., Obare, F., Katahoire, A. and Kibenge, D. 20II. "HIV infection and schooling experiences of adolescents in Uganda." In: Gobopamang Letamo (ed). Social and Psychological Aspects of HIV/AIDS and their Ramifications. Rijeka: InTech, pp. 73-88.

Bogale, G.W., Boer, H. and Seydel, E.R. 201 I. "Effects of a theory-based audio HIV/AIDS intervention for illiterate rural females in Amhara, Ethiopia." AIDS Education and Prevention 23, (I):25-37.

Bond, V., Chase, E. and Aggleton, P. 2002. "Stigma, HIV/AIDS and prevention of mother-to-child transmission in Zambia." Evaluation and Program Planning 25, (4):347-356.

Bühler, C. and Kohler, H.P. 2003. "Talking about AIDS: The influence of communication networks on individual risk perceptions of HIV/AIDS infection and favored protective behaviors in South Nyanza District, Kenya." Demographic Research SI, (13):398-438.

Centers for Disease Control and Prevention. 2009. HIV testing among adolescents. www.cdc.gov/ HealthyYouth; Accessed on May 19, 2010.

Chatterji, M., Murray, N., London, D., Anglewicz, P. 2005. "The factors influencing transactional sex among young men and women in 12 sub-Saharan African countries." Biodemography and Social Biology 52, (I\&2):56-72.

De Tolly, K. and Alexander, H. 2009. "Innovative use of cellphone technology for HIV/AIDS behaviour change communications: Three Pilot Projects." Cellphones4HIV. http://mobileactive.org/research/ innovative-use-cell-phone-technology-hiv-aidsbehaviour-change-communications-3-pilot-proje. Accessed May 20, 2011.

Dowse, R., Ramela, T., Barford, K.L. and Browne, S. 2010. "Developing visual images for communicating information about antiretroviral side effects to a low-literate population." African Journal of AIDS Research 9, (3):213-224.

Essien, J.E., Mgbere, O., Monjok, E., Ekong, E., Holstad, M.M. and Kalichman, S.C. 2011. "Effectiveness of a video-based motivational skills-building HIV risk-reduction intervention for female military personnel." Social Science \& Medicine 72, (I):63-7I.
Family Health International (FHI). 2005. Strategic behavioral communication (SBC) for HIV/AIDS: A framework. Arlington: Family Health International.

Family Health International (FHI). 2002. Behavior change communication (BCC) for HIV/AIDS: A strategic framework. Arlington: Family Health International.

Fishbein, M. and Ajzen, I. 1975. Belief, Attitude, Intention, and Behavior: An Introduction to Theory and Research. Reading: Addison-Wesley.

Gallanta, M. and Maticka-Tyndale, E. 2004. "Schoolbased HIV prevention programmes for African youth." Social Science and Medicine 58, (7): I337I35I.

Halpern, C.T., Mitchell, E.M.H., Farhat, T. and Bardsley, P. 2008. "Effectiveness of web-based education on Kenyan and Brazilian adolescents' knowledge about HIV/AIDS, abortion law, and emergency contraception: Findings from TeenWeb." Social Science \& Medicine 67, (4):628637.

Helleringer, S. and Kohler, H.P. 2005. "Social networks, perceptions of risk, and changing attitudes towards HIV/AIDS: New evidence from a longitudinal study using fixed-effects analysis." Population Studies 59, (3):265-282.

Joint United Nations Programme on HIV/AIDS [UNAIDS]. 20 I0. UNAIDS Report on the Global AIDS Epidemic 2010. Geneva: UNAIDS.

Kaaya, S.F., Mukoma, W., Flisher, A.J. and Klepp, K.I. 2002. "School-based sexual health interventions in sub-Saharan Africa: A review." Social Dynamics: A Journal of African Studies 28, (2):64-88.

Kenya National Bureau of Statistics [KNBS] and ICF Macro. 2010. Kenya Demographic and Health Survey 2008-2009. Calverton, MD: KNBS and ICF Macro.

Kirby, D., A. Obasi, and B.A. Laris. 2006. "The effectiveness of sex education and HIV education interventions in schools in developing countries." In Preventing HIV/AIDS in young people: $A$ systematic review of the evidence from developing countries, eds. D.A. Ross, B. Dick and J. Ferguson, World Health Organization (WHO) Technical Report Series No. 938, pp. 103-150. Geneva: WHO.

Kohler, H.P., Behrman, J.R. and Watkins, S.C. 200 I. "The density of social networks and fertility decisions: Evidence from South Nyanza district, Kenya." Demography 38, (I):43-58.

Lazarsfeld, P.F., Berelson, B. and Gaudet, H. 1948. The People's Choice. New York: Columbia University Press.

Livingstone, S. 2002. Young People and New Media: Childhood and the Changing Media Environment. London: Sage Publications Ltd. 
Luke, N. 2003. "Age and economic asymmetries in the sexual relationships of adolescent girls in subSaharan Africa." Studies in Family Planning 34, (2):67-86.

Marston, C. and King, E. 2006. "Factors that shape young people's sexual behaviour: A systematic review." Lancet 368, (9547): I 58 I-I 586.

Mathew, R.M., Shugaba, A.I. and Ogala, W.N. 2006. "Parents-adolescents communication and HIV/ AIDS in Jos North Local Government Area, Plateau State, Nigeria." Journal of Medical Sciences 6, (4):537-545.

Mathews, C., Boon, H., Flisher, A.J. and Schaalma, H.P. 2006. "Factors associated with teachers' implementation of HIV/AIDS education in secondary schools in Cape Town, South Africa." AIDS Care I8, (4):388-397.

Mitchell, E.M.H., Halpern, C.T., Kamathi, E.M., and Owino, S. 2006. "Social scripts and stark realities: Kenyan adolescents' abortion discourse." Culture, Health \& Sexuality 8, (6):5 I5-528.

Muñoz-Silva, A., M. Sánchez-García, C. Nunes, and A Martins. 2006. "Gender differences in condom use prediction with Theory of Reasoned Action and Planned Behaviour: The role of self-efficacy and control." AIDS Care 19(9): I I77-I I8I

Nyblade, L., Pande, R., Mathur, S., MacQuarrie, K., Kidd, R., Banteyerga, H., Kidanu, A., Kilonzo, G., Mbwambo, J. and Bond, V. 2003. Disentangling HIV and AIDS stigma in Ethiopia, Tanzania and Zambia. Washington, DC: International Center for Research on Women.

Nzioka, C. 200I. "Perspectives of adolescent boys on the risks of unwanted pregnancy and sexually transmitted infections: Kenya." Reproductive Health Matters 9, (17): 108-II 7.

Obare, F., Birungi, H., Katahoire, A., Nkayivu, H., and Kibenge, A.D. 2009. Special needs of in-school HIV positive young people in Uganda. Nairobi: Population Council, Reproductive Health Program.

Oshi, D.C., Nakalema, S. and Oshi, L.L. 2005. "Cultural and social aspects of HIV/AIDS sex education in secondary schools in Nigeria." Journal of Biosocial Science 37, (2): I 75-I83.

Reinecke, J., P. Schmidt, and I. Ajzen. 1996. "Application of the Theory of Planned Behavior to adolescents' Condom Use: A Panel Study."
Journal of Applied Social Psychology 26(9):749-772. Rogers, E.M., Vaughan, P.W., Swalehe, R.M.A., Rao, N., Svenkerud, P. and Sood, S. 1999. "Effects of an entertainment-education radio soap opera on family planning behavior in Tanzania." Studies in Family Planning 30, (3): 193-21I.

Singhal, A., Cody, M.J., Rogers, E.M. and Sadibo, M. 2004. Entertainment-Education and Social Change: History, Research, and Practice. Mahwah: Lawrence Erlbaum Associates, Inc.

Singhal, A. and Rogers, E.M. 1999. EntertainmentEducation: A Communication Strategy for Social Change. Mahwah: Lawrence Erlbaum Associates, Inc.

Skinner, D. and Mfecane, S. 2004. "Stigma, discrimination and its implications for people living with HIV/AIDS in South Africa." Sahara Journal I, (3): I57-I64.

Sullivan, K.T., L.A. Pasch, T. Cornelius, E. Cirigliano. 2004. "Predicting participation in premarital prevention programs: The Health Belief Model and social norms." Family Process 43(2): 175-193.

Thurman, T.R., Brown, L., Richter, L., Maharaj, P. and Magnani, R. 2006. "Sexual risk behavior among South African adolescents: Is orphan status a factor?" AIDS and Behavior 10, (6):627-635.

Vanlandingham, M.J., S. Suprasert, N. Grandjean, W. Sittitrai. 1995. "Two views of risky sexual practices among Northern Thai males: The Health Belief Model and the Theory of Reasoned Action." Journal of Health and Social Behavior 36(2): 195-2I2.

Varga, C.A. 2003. "How gender roles influence sexual and reproductive health among South African adolescents." Studies in Family Planning $34,(3): 160-172$.

Ward, V. and Mendelsohn, J. 2009. Supporting the educational needs of HIV-positive learners in Namibia. Paris: United Nations Educational, Scientific and Cultural Organization.

Watkins, S.C. 2004. "Navigating the AIDS epidemic in rural Malawi." Population and Development Review 30, (4):673-705.

Wood, K and Jewkes, R. 2006. "Blood blockages and scolding nurses: Barriers to adolescent contraceptive use in South Africa." Reproductive Health Matters 14, (27): 109-I I8. 